SOLVED PROBLEMS MACHINE ELEMENTS

VOLUME 1 
- 


\title{
SOLVED PROBLEMS \\ MACHINE ELEMENTS \\ VOLUME 1
}

\author{
İ. Hüseyin Filiz
}

Professor

Gaziantep

2020 


\section{(C) Copyright 2020}

Printing, broadcasting and sales rights of this book are reserved to Akademisyen Publishing House Inc. All or parts of this book may not be reproduced, printed or distributed by any means mechanical, electronic, photocopying, magnetic paper and/or other methods without prior written permission of the publisher. Tables, figures and graphics cannot be used for commercial purposes without permission. This book is sold with banderol of Republic of Turkey Ministry of Culture.

ISBN

978-625-7795-11-1

\section{Book Title}

Solved Problems Machine Elements Volume 1

\section{Editors}

İ. Hüseyin Filiz

\section{Publishing Coordinator}

Yasin DİLMEN

\section{Page and Cover Design}

Typesetting and Cover Design by Akademisyen

\section{Publisher Certificate Number}

47518

\section{Printing and Binding \\ Printing press Vadi}

Bisac Code

TEC046000

DOI

10.37609/akya.742

\section{GENERAL DISTRIBUTION}

\section{Akademisyen Kitabevi A.Ş.}

Halk Sokak 5 / A

Yenişehir / Ankara

Tel: 03124311633

siparis@akademisyen.com 


\section{CONTENTS}

PREFACE vi

LIST OF SYMBOLS viii

Chapter 1

INTRODUCTION 1

Chapter 2

STRESS ANALYSIS

Chapter 3

DEFLECTION ANALYSIS 63

Chapter 4

DESIGN FOR STATIC STRENGTH 139

Chapter 5

DESIGN FOR FATIGUE STRENGTH

Chapter 6

TOLERANCES AND FITS

Chapter 7

DESIGN OF POWER SCREWS

Chapter 8

DESIGN OF BOLTED JOINTS

Chapter 9

DESIGN OF RIVETED JOINTS

Chapter 10

DESIGN OF WELDED JOINTS

APPENDIX

REFERENCES 


\section{PREFACE}

This book has been prepared for mechanical engineering students as a complementary book to be used in the course of "Mechanical Engineering Design or Design of Machine Elements. It is not the author's intention to use this book as a text book but it may be considered as a complementary book especially for the solution of problems in the area of Mechanical Engineering Design. Methodic approaches developed for the solutions are provided in order to improve the efficiency of teaching Machine Elements course. Most of the problems are selected from previous years' examinations sheets. Short explanations of some subjects have been included for a beter understanding of the solution of the problems.

The Author's previous book " Problems on the Design of Machine Elements" is rearranged, introductory sections of the Chapters have been extended, different types of problems are added and an effort is made to make the examples more practical. Owing to an increased volume of the contents, it was considered to be more practical and usable to present the book in two parts, especially for students of Mechanical Engineering.

This first part is devoted to the subjects : stress analysis, deflection analysis, design for static strength, design for fatigue strength, tolerances and fits, design of power screws, design of bolted joints, design of riveted joints and design of welded joints.

Second part is devoted to the subjects: design of mechanical springs, selection of anti-friction bearings, design of journal bearings, gearing and kinematic analysis of gear trains, design of spur gears, design of helical gears, design of worm gears, design of bevel gears, design of brakes and design and selection of flexible mechanical elements such as belts and chains.

The subjects are treated in seperate sections and they are incorporated with introductory sections in which a brief summary of design and/or selection principles of 
the respective elements are given. At the end of each section some selected problems are included to be solved by the students themselves.

SI units are used in this book. Material selection process is not included, but material properties are stated in the problems. Some design factors used in the solution of the problems may be found in the figures and tables given in the Appendix. They are adopted from some of the references given at the end of the book. The reasons of including the tables and figures are first, to give the students the opportunity to find the numerical values of some of the design factors without needing any other source and second, to be consistent with the text used in Machine Elements Courses.

I would like to thank to my previous years' undergraduate students for their criticism and suggestions on the contents of the book. Mr. Haci Çelik, in preparing the title page and the help in the printing stage of the book is very much appreciated.

Special appreciation is extended to my wife Prof. Dr. Ayten Filiz and my daughters Gökçe and Bilge for their continuous support in my academic studies.

August, 2020

Dr. I. Hüseyin Filiz 


\section{LIST OF SYMBOLS}
A Area; constant
a constant; dimension
B constant
b constant; fatigue strength exponent
C coefficient; spring index; column-end condition
constant; center distance
c clearance; distance
D,d Diameter
E Modulus of elasticity
e Eccentricity; efficiency; strain value;
F Force; face width
f Frequency; coefficient of friction
G Shear modulus of elasticity
g Gravitational constant
$\mathrm{H} \quad$ Hardness number; power
h thickness; nut height
I Moment of inertia
J Polar moment of inertia
K Stress concentration factor;
k Spring scale; endurance limit modifying factor; radius
of gyration; stiffness
L Length; life; lead
1 Length 


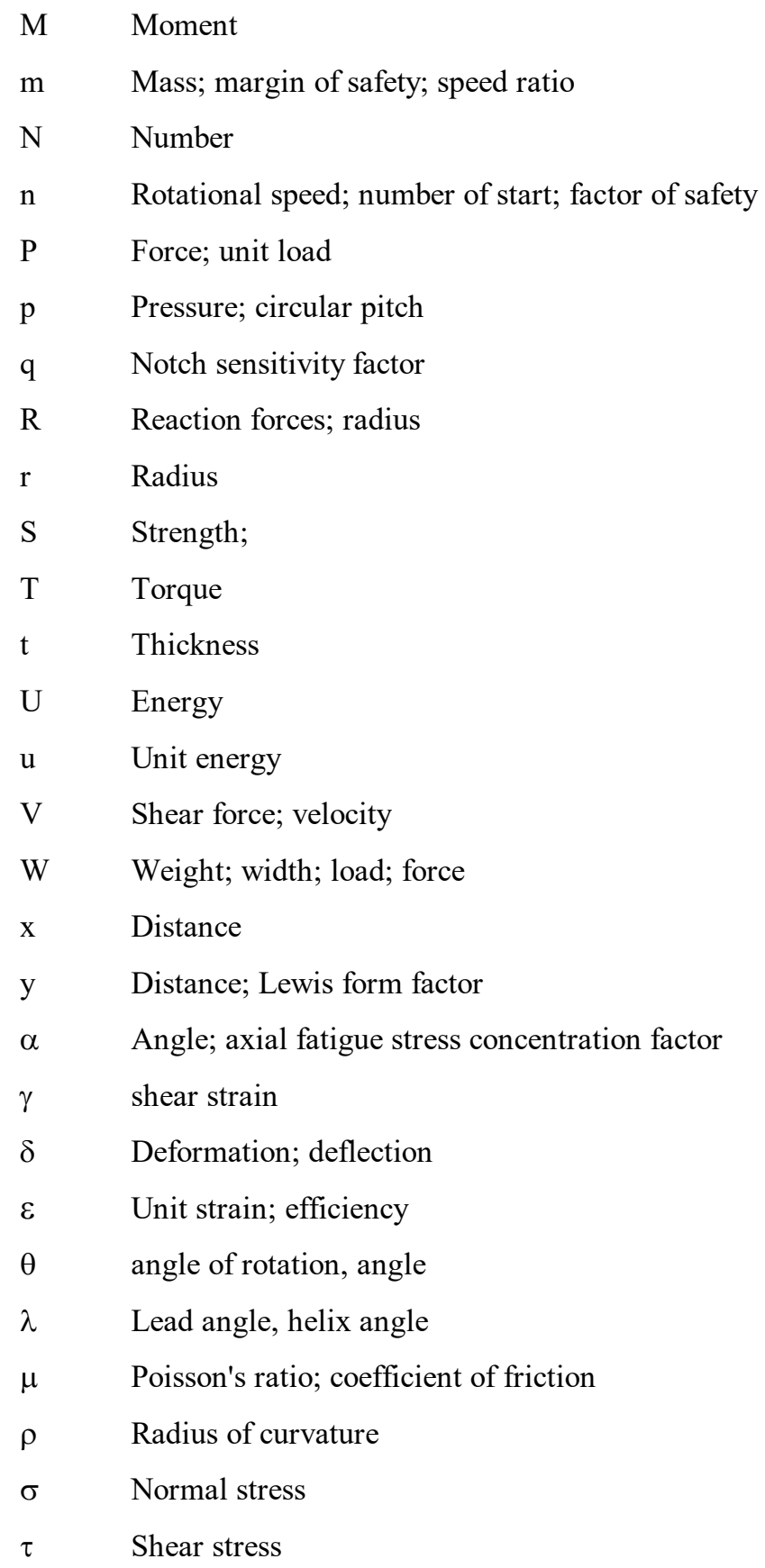




\section{REFERENCES}

1. Dieter,G.," Engineering Design ", McGraw-Hill, Tokyo, 1983

2. Shigley, E. J. and Mitchell, L. D., " Mechanical Engineering Design", McGraw-Hill, Tokyo, 1983

3. Shigley, E. J. and Mischke,C.R., " Mechanical Engineering Design", Fifth Edition,McGraw-Hill, Singapore, 1989

4. Hamrock,B., Schmid, B.J. and Jacobson B.," Fundamentals of Machine Elements", McGraw-Hill, New York,2005

5. Wileman,J., Choudhurry, M., Green, I.," Computation of Member Stiffness in Bolted Connections" Journal of Machine Design, Vol.113,432-437,1991.

6. Filiz, İ. H., Akpolat A., Güzelbey İ.H., " Stiffness of Bolted Members", Tr. J. of Engineering and Environmental Sciences, 20(1996) 273-279.

7. Spotts, M. F., " Design of Machine Elements", Prentice-Hall, New Jersey, 1971.

8. Faires V. M., "Design of Machine Elements", The Macmillan Company, New York, 1962.

9. Sines G. and Weisman, J. L. "Metal Fatigue", McGraw Hill,New York,1959, pp.296-298.

10. Filiz, İ.H., "Computer Aided Design of Feed Drives for High Performance NC Machine Tools", PhD Thesis, UMIST, UK, 1981.

11. Filiz, İ.H. ve Bell, R., “Axial Preload on Bearings”, Machine Design, April 25, 1991, pp 78-82.

12. Peterson R.E. " Stress Concentration Factors in Design ", New York, John Wiley \& Sons, Inc., 1953.

13. Filiz, İ.H., "Sayısal Kontrollu Takım Tezgahlarında Bilyalı Paso Milleri, Bölüm 1- Analiz", 1. Ulusal Makina Tasarım ve İmalat Kongresi, 19-21 Eylül 1984, ODTÜ, Ankara, Bildiri Kitabı, Sayfa 139-147. 
14. Filiz, İ.H., "Sayısal Kontrollu Takım Tezgahlarında Bilyalı Paso Milleri , Bölüm 2- Bilgisayar Yardımıyla Seçim”, 1.Ulusal Makina Tasarım ve İmalat Kongresi, 19-21 Eylül 1984, ODTÜ, Ankara.

15. Norton, Robert L." Machine Design An Integrated Approach", Prentice Hall, Third Edition,2006, New Jersey.

16. http://www.ndt-ed.org/EducationResources/CommunityCollege 